
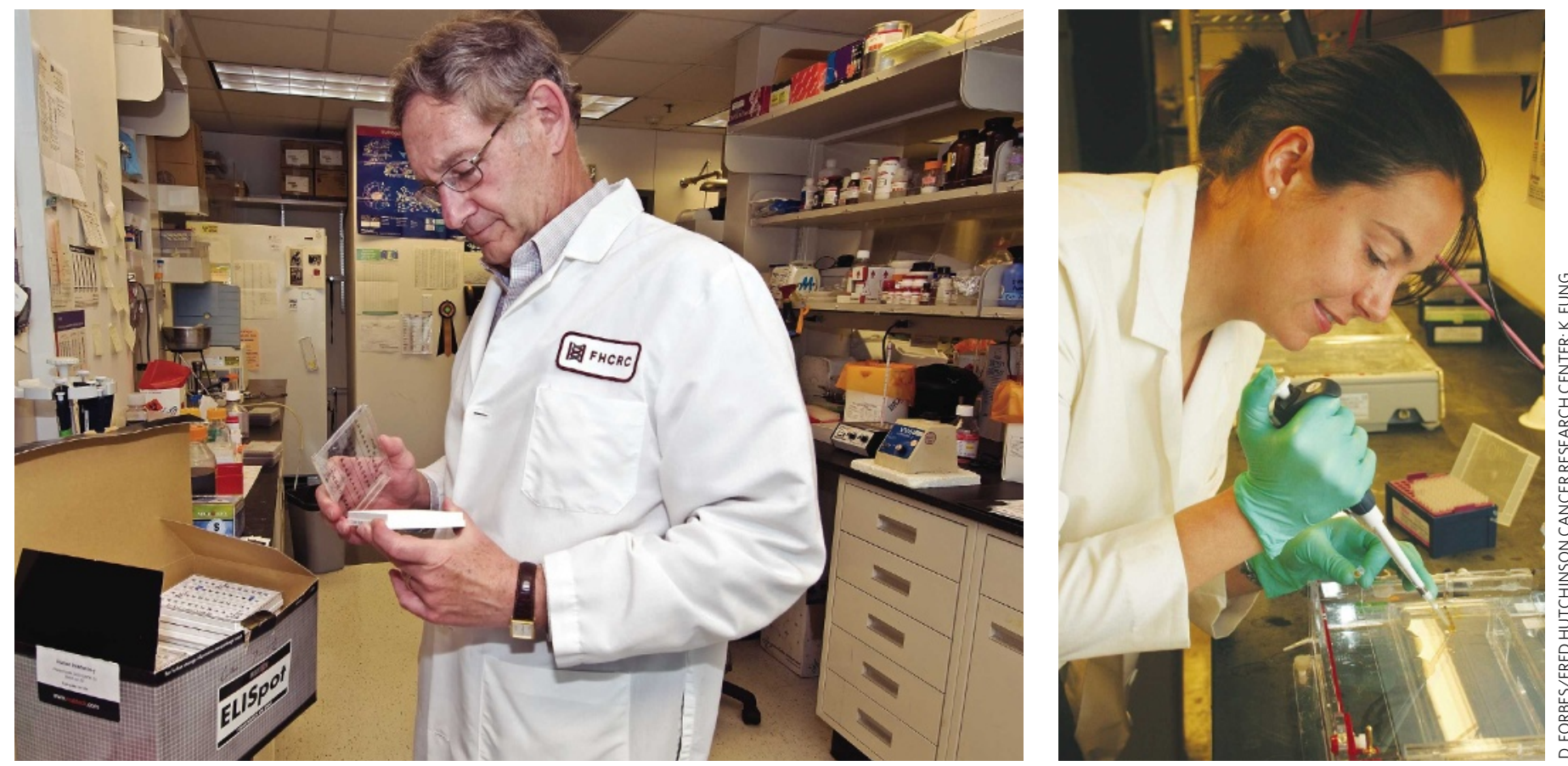

\title{
THE NEXT SHOT
}

\section{Researchers trying to develop an HIV vaccine have endured two decades of setbacks. Erika Check Hayden meets a veteran still engaged in the fight - and a rookie willing to join in anyway.}

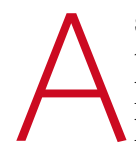

s Larry Corey boarded a plane on the night of 18 September 2007, he was in shock. For four years, he had been in charge of clinical trials of a vaccine against HIV. Although previous vaccines had failed, Corey was optimistic that this one might work because it took a new approach. He thought it was the best hope against HIV. But that afternoon, Corey had met with scientists who had reviewed the early trial results. Not only did the vaccine not work, they told him, it might actually have made some people in the trial, called the STEP Study, more vulnerable to infection.

On the long flight from Chicago home to Seattle that night, Corey cycled through stages of grief, regret and resolve. He had led the search for an HIV vaccine since its inception more than two decades ago. Now, as head of the flagship HIV Vaccine Trials Network run by the US National Institutes of Health (NIH), Corey had to make some difficult decisions. He had to decide what to tell the trial volunteers, and he had to think about the millions of other people who might contract HIV in the future. What could be done to make the vaccine that they so desperately needed?
As Corey pondered these issues, another HIV researcher was mulling over a decision of her own. Colleen Doyle is 32 years younger than Corey and had earned her PhD only three months before. Yet she had just received a job offer from the University of Chicago. The position was a rare and precious opportunity for such a young scientist. But there was a catch: if she took the job, she would have to stop her investigations of how a vaccine could arm the body against HIV.

Both Corey and Doyle (pictured above) had reached turning points, and their decisions could prove crucial to the search for a vaccine. The disappointing failure of the STEP trial marked one of the most difficult moments in HIV vaccine history. It told Corey and other scientists that after decades of work, they still did not understand how to prevent HIV from overwhelming the immune system. And critics were calling for an end to the vaccine hunt, so that some of the money - more than US\$900 million was spent last year (see graph, overleaf) - could go towards drug treatments.

But where some see an end to the field, Corey and other researchers see a new beginning. They say that basic research will eventually answer the outstanding questions about HIV, if talented researchers like Doyle can be coaxed into the fight. "We need a period of solid, quiet science, even if it takes a decade," says virologist and long-time HIV vaccine researcher John Moore from Weill Cornell Medical College in New York.

With this resolution, veteran vaccine researchers are facing a new reality: they will not be the ones to end HIV. They must now pass the baton to a new generation of scientists. "The real next step is going to come from outside this room," declared Adel Mahmoud of Princeton University in New Jersey, at an HIV vaccine summit this March in Bethesda, Maryland. But Doyle had watched the first generation of vaccine hunters endure decades of frustration. So the question she faced last September was, did she really want to heed that call? 
Born in 1947, Corey grew up in Detroit and decided at age 10 to become a doctor. As an undergraduate at the University of Michigan in Ann Arbor, Corey started dating Amy Glasser, whose dad had just finished supervising the field trials of the Salk polio vaccine. So when Amy and Larry were married in 1969, Jonas Salk was a guest at their wedding. No one foresaw that Corey would one day emulate Salk's quest to vaccinate humanity against a terrifying viral scourge; at the time, Larry was leaning towards cardiology.

That changed in 1975, when Corey began a fellowship with King Holmes, an expert in sexually transmitted infections at the University of Washington in Seattle, and discovered that he loved research.

"That moment of discovery is a wonderful thing," he says, sitting in his office decades later

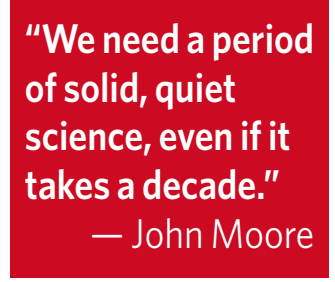

his selection, in 1987, as chair of the NIH's AIDS Clinical Trials Group (ACTG).

That year, the first anti-AIDS drug, zidovudine, was approved. But it wasn't a cure, and patients and activists in the United States were growing angry about what they saw as the government's slow response to the disease. As leader of the ACTG, Corey was a frequent target for activist groups, such as the AIDS Coalition to Unleash Power (ACT UP) in New York.

Corey felt the activists' frustration acutely. Each year, he would invite a patient who had contracted AIDS to the first-year medical school class he co-taught. He would tell students to shake the patient's hand, to touch the patient; that the patient was no different from anyone else, and couldn't infect them with the virus. But every year he had to find a new patient because the previous year's speaker had at the Fred Hutchinson Cancer Research Center in Seattle. Now a lanky, greyhaired 61-year-old, Corey seems laid-back, sporting a short-sleeved polo shirt and telling stories about his grandkids. But inside the casual exterior, Corey is fiercely driven, says longtime friend Anthony Fauci, head of the National Institute of Allergy and Infectious Disease (NIAID) in Bethesda, Maryland. "Larry sees his endpoint, he sees his goal, and he goes after it," Fauci says. "He always asks the big-picture questions - he's rarely involved in trivial things."

That was true from the beginning of Corey's career. In 1977, he and Holmes began working with the company Burroughs Wellcome to test a new drug, acyclovir, against herpes. Five years later, their studies led the US Food and Drug Administration to approve the drug, which was directly targeted against a viral enzyme and therefore less toxic than previous antiviral treatments. Barely 35 years old, Corey had already achieved something most scientists never do in a lifetime: the successful development of a drug.

\section{A fatal disease emerges}

The following year, the US Centers for Disease Control and Prevention began issuing bulletins about a disease that would soon be named AIDS. It would later be traced to the human immunodeficiency virus, HIV. As a diagnostic virologist at a regional medical school, Corey began seeing patients with AIDS. Like other doctors, he was troubled by the disease, which did not respond to any known treatment. But Corey at least had experience in developing antiviral drugs, and this led to died. "In infectious disease, we had the world's best drugs - antibiotics are incredible," Corey recalls. "And all of a sudden we had this fatal illness, and we were pretty impotent against it."

Corey spent five years leading the ACTG. During that time, molecular biologists delivered a nuts-and-bolts understanding of how the virus worked. That enabled them to emulate the acyclovir example and deliver three anti-retroviral drugs designed to fight HIV. Soon, combination therapies would be available for patients with HIV in many wealthy countries. They were sorely needed: AIDS was claiming a shocking and ever-growing human and economic toll. The world needed an HIV vaccine. And Corey wanted to be the man who made it.

\section{GLOBAL INVESTMENT IN HIV VACCINE} RESEARCH AND DEVELOPMENT

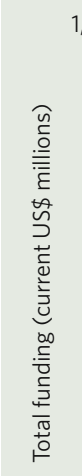

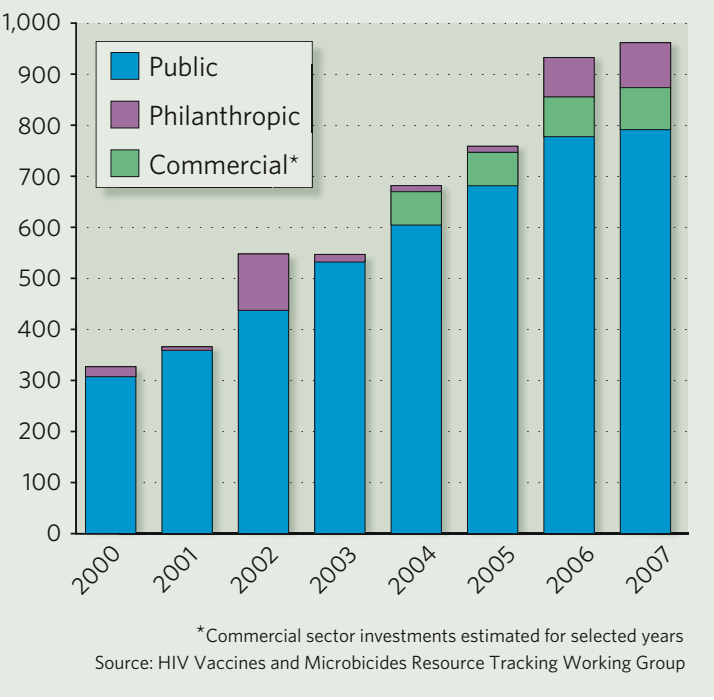

By 1992, AIDS was the leading cause of death for young adult men in the United States. One of them was Lenny, a distant relative of Doyle's. Both had grown up in a blue-collar community south of Detroit called 'Downriver'. One year, Doyle noticed that Lenny had begun to look sick. But it was only when he was close to death that her parents told her he had AIDS. Even then, Doyle didn't understand why the grown-ups around her seemed so hush-hush. She had seen AIDS on the news and knew that it was a terrible disease that nobody seemed to understand, but she didn't see how it differed from other fatal illnesses, such as cancer.

\section{Childhood beginnings}

For as long as she can remember, Doyle has wanted to be a scientist. Her favourite childhood toy was a microscope an uncle gave her. She would use it to look at anything and everything, without even really knowing what she was looking for. Then there were the chemistry sets. And the rock polisher. "Science was her own little world," her sister Katie says.

Perched on a stool in her lab, 29-year-old Doyle seems right at home. Clad in jeans and a black hoodie, she pipettes reagents into test tubes sitting in an ice bath while a U2 CD plays in the background. "I've always enjoyed just being in the lab - that's where I feel most comfortable," she says. She joined her first lab in 1997 at the University of Michigan. She wanted to study cancer or HIV, the two big medical mysteries of her youth, but the only lab that would hire her with no experience was a plant genetics lab. She took the job anyway.

The following summer, when Doyle went home, she inexplicably began losing weight. By the time she returned to university that autumn, she had lost 16 kilograms. She was exhausted all the time, her joints were swollen and her hands and wrists would feel frozen. Doctors found that she had an abnormally high sedimentation rate in her blood, often an indicator of inflammation or even cancer. Yet they couldn't find an infection or a tumour. Eventually she withdrew from university and went back home to live with her parents.

Doyle's hometown doctor recognized that her baffling symptoms could be signs of an autoimmune disease. She was referred to a rheumatologist, who quickly diagnosed lupus, an incurable illness caused by the body reacting destructively to its own proteins and DNA. She began taking drugs and avoiding too much sun exposure, as it seemed to set off 'flares'. That same year, her sister was 


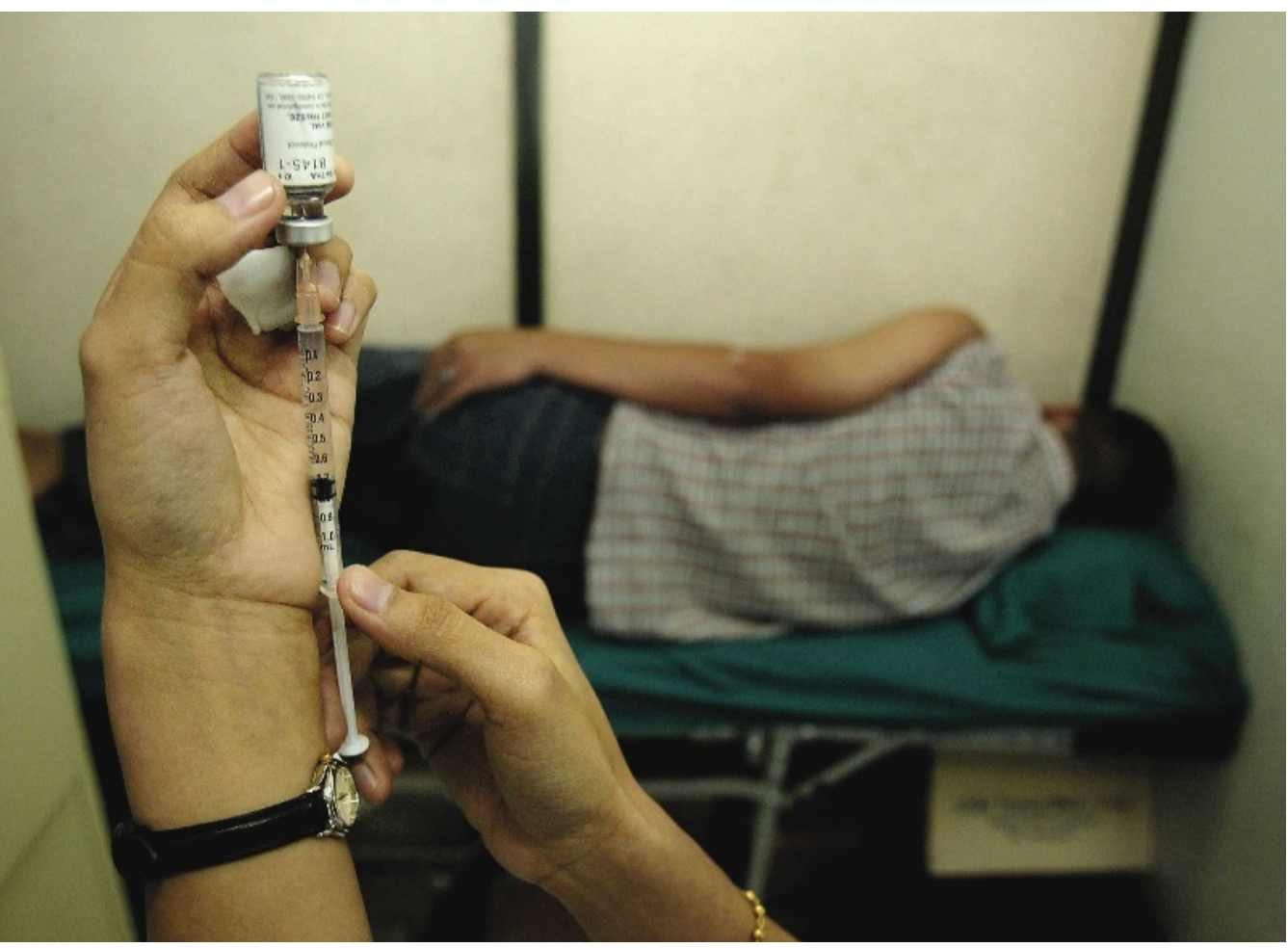

Long shot: researchers were hopeful that an HIV vaccine could turn T cells against the virus.

diagnosed with ulcerative colitis, an inflammatory disease thought to have autoimmune origins. The sisters then found out that many of their relatives had similar conditions.

By autumn 1998, Doyle felt well enough to return to university and started working in a biochemistry lab. Her passion for science was undiminished. But one thing had changed: she now wanted to study autoimmunity, to understand the illnesses haunting her family.

\section{Building on a legacy}

As the millennium turned, Corey, too, was on a mission. He thought that making vaccines couldn't be too much harder than making drugs and became involved in the first tests of vaccine prototypes. The legacy of Jonas Salk - who had also tried to develop an HIV vaccine - was not far from Corey's mind. Then, in 2000, the NIAID reorganized its vaccine efforts, and Corey won a US\$29-million grant to head the newly formed HIV Vaccine Trials Network, which would plan and conduct clinical trials of vaccine candidates around the globe. The NIAID hoped that its investment in vaccine development - by far the largest in the world - would help make up for industry's indifference.

Salk's legacy wasn't just on Corey's mind - it was about all anyone had to go on. Salk's polio vaccine contained dead polio virus. It trained the immune system to make proteins called antibodies that recognize the virus and could later be summoned to fight off the live polio virus if it invaded the body. Scientists hoped this 'antibody approach' would work against HIV.

But it didn't. Researchers such as Dennis Burton at the Scripps Research Institute in La Jolla, California, have found that some "broadly neutralizing' antibodies do block HIV from infecting cells. A handful of people who are infected with the virus but never get sick with AIDS make these antibodies, which recognize proteins in HIV's outer coat even when they mutate to try to evade the immune system. Unfortunately, most people make other, ineffective antibodies that don't recognize the virus when it mutates. In 1998, Vaxgen, a biopharmaceutical firm based

"The field has
jumped into vaccine
design without
really knowing how
HIV is working."
$\quad$ - Colleen Doyle

T cells. They were especially focused on 'killer' $\mathrm{T}$ cells, which destroy cells infected by viruses.

In the T-cell game, pharmaceutical company Merck was the leader. The firm had made a vaccine from a common cold virus, the adenovirus, which carried three HIV genes into the host's cells, where they were translated into proteins. Merck hoped that the vaccine would prime T cells to recognize the HIV proteins and destroy cells containing them. The vaccine had looked promising in some tests in monkeys.

The Merck vaccine was the best candidate on the horizon, and Corey was excited about its potential. In 2001, he convinced Merck to form a partnership to test it in a 435-person study that began in 2003. The vaccine generated strong T-cell responses, clearing the way for a second, larger trial in 2004 - the STEP Study. STEP was crucial because it would reveal for the first time whether the vaccine could actually blunt HIV infection. It included 3,000 people in North America, South America, the Caribbean and Australia.

As the trial got under way, Corey was feeling confident. He had maneouvered his network into a prime position at the helm of the world's most promising HIV vaccine trial. It was guaranteed to be a landmark. If Corey's confidence paid off, he would strike a historic blow against a viral foe he had fought for 17 years.

\section{Keen insight}

Doyle's prospects were also brightening. After resolving to study autoimmunity, she had started taking immunology classes and by the time she graduated in 2001, she knew what she wanted to study more precisely than most freshly minted graduates. She was interested in the process that teaches the immune system to distinguish foreign pathogens from harmless human proteins. Doyle started graduate school that year at the University of Chicago. In 2003, she joined the lab of Martin Weigert, who was doing ground-breaking work on autoantibodies, which attack the body's own tissues.

Doyle's interest in autoin South San Francisco, California, used the antibody approach in the world's first large trial to test whether an HIV vaccine was clinically effective. Vaxgen's vaccine contained pieces of the HIV coat protein called gp120. But that trial and a subsequent one failed miserably. The 7,500 volunteers in the trials did make antibodies to the vaccine, but they were of the weak variety that does not stop the virus ${ }^{1,2}$.

As Corey took the reins of the vaccine network, scientists were changing tactics and turning to another branch of the immune system, the immunity soon steered her back towards HIV. Midway through her graduate work, she noticed a paper from immunologist Barton Haynes at Duke University in Durham, North Carolina. His team had shown that two naturally produced broadly neutralizing antibodies against HIV also reacted against cardiolipin, a molecule found in mitochondria, the cell's powerhouses ${ }^{3}$. The immune system usually has 'tolerance' mechanisms that train antibodies not to attack the body's own tissues. But Haynes thought that these same mechanisms might 
inadvertently block the production of broadly neutralizing antibodies against HIV that are also autoantibodies — and that might explain why so few people make them.

Haynes's idea made sense to Doyle, who wondered whether her mice made components of autoantibodies so often because some of them could help fight HIV and other infections. "The Haynes paper seemed like a perfect explanation for what we were seeing," she says.

When Doyle began looking for postdoctoral fellowships the next year, she e-mailed David Nemazee at Scripps. Nemazee is an expert in tolerance, and he too was intrigued by Haynes's paper. Nemazee e-mailed Doyle a copy of a grant he was about to submit to the NIH in collaboration with Burton, who worked a floor below Nemazee. The proposal would test Haynes's hypothesis that tolerance prevented the body from making broadly neutralizing antibodies against HIV because they looked similar to autoantibodies. The project seemed perfect for Doyle, offering her a chance to work with two renowned scientists, and to study two problems that had affected her own life. When NIAID approved the \$1.25-million, 5-year grant, she gladly signed on for the project.

\section{Glowing testimonials}

Doyle moved to La Jolla in April 2007, but came back to Chicago in June to celebrate her graduation ceremony. At dinner with her family, Weigert told Doyle's parents how impressed he was with the young scientist. She had been one of his best students: focused and driven, with a gift for experimental design. "He said, 'Do you realize who she is? Do you realize what she's doing, and how important she is?"', Doyle's sister remembers. Once in La Jolla, Nemazee too would become impressed by Doyle because she seemed more confident than most young scientists. "Colleen can think for herself, and ignore you when it's appropriate," he says.

Doyle would need that confidence to see her through the ambitious work that Nemazee and Burton had in mind. The plan was to make mice that carry human genes for broadly neutralizing antibodies against HIV. Doyle would then test whether the mice used tolerance mechanisms to block the assembly of working antibodies. If the mice quashed the broadly neutralizing antibodies, it would suggest that Haynes was right. Haynes, too, was doing experiments to test the theory.

The results should help to explain why the antibody approach to HIV vaccines had failed so far, and inform the design of better vaccine

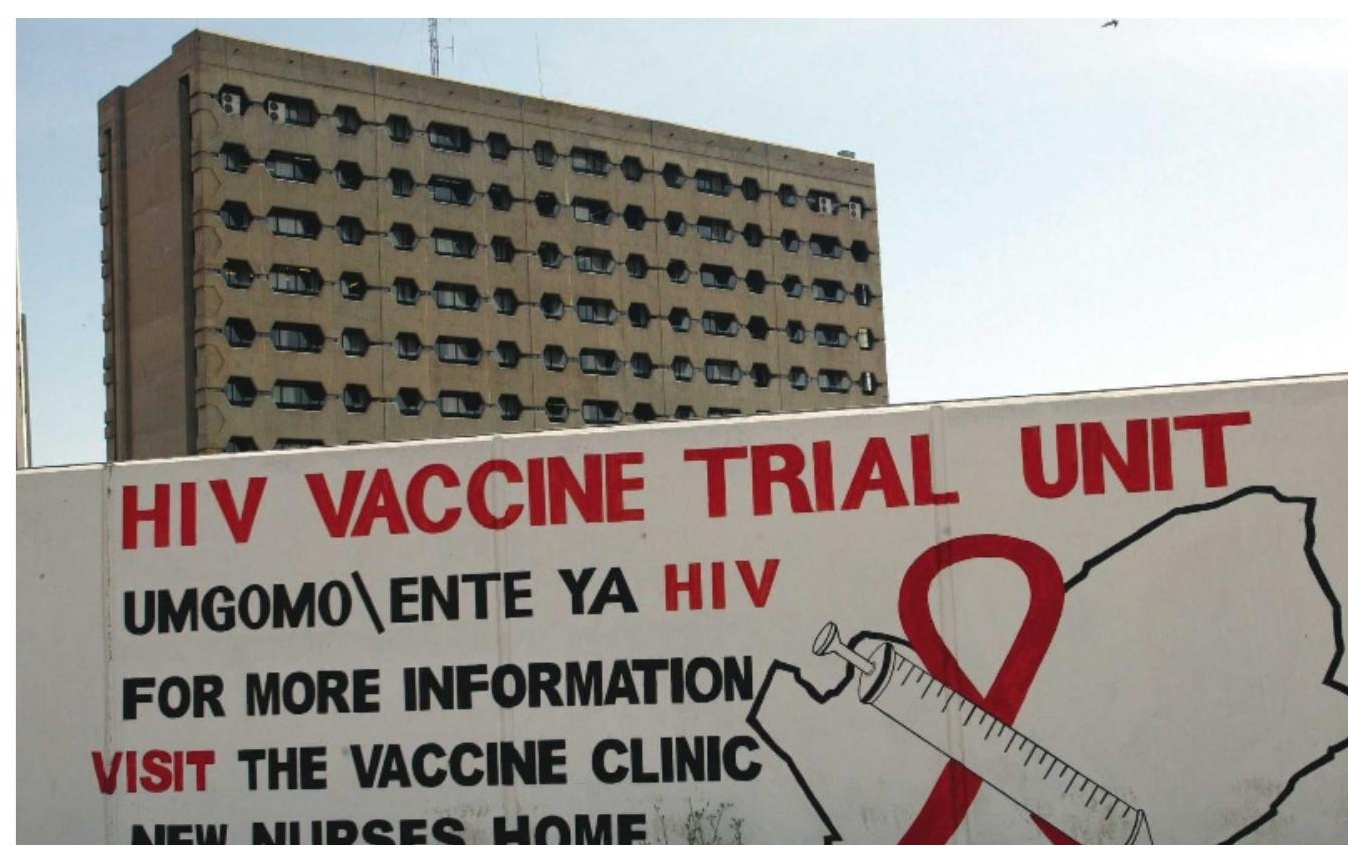

Thousands of patients have participated in HIV vaccine trials around the world.

candidates. If tolerance mechanisms do block the production of broadly neutralizing antibodies, then researchers might need to turn off tolerance to make a successful vaccine. And even if tolerance doesn't suppress the broadly neutralizing antibodies, the mouse model could still be used to test whether vaccine candidates can stimulate the right antibody responses.

By September, Doyle had almost finished constructing the genetic materials she would use to modify the mice. And that's when Weigert called her out of the blue: just half a year after she had left his lab, a job had come up and Weigert wanted her back at the University of Chicago. He offered her a three-year post studying autoimmunity, one that could become tenured. It would almost certainly end her studies of HIV, yet Doyle found herself leaning towards taking the job. The unexpected offer just seemed too good to let go.

That same month, Corey too received unexpected news - but his was devastating. "You need to stop the trial," he was told by those on the STEP Study monitoring board. "There's no chance the vaccine is going to work." As scientists analysed the data in the coming weeks, they would confirm that the vaccine had made some people more vulnerable to HIV.

After flying back to Seattle, Corey called Glenda Gray in South Africa and told her to stop STEP's sister trial, Phambili, which had just started in January. The next day, he called Fauci, whose agency helped fund the STEP trial. "There's no way to torture these data to look good," Corey told his old friend.

As the news reached the rest of the HIV vaccine field, some called it a crisis. Robert Gallo, co-discoverer of HIV, called the STEP results a catastrophe on the same level as the Challenger disaster. Further analysis of the trial results showed that uncircumcised men with strong immune responses to the adenovirus had been made most vulnerable by the vaccine. But researchers didn't know why.

\section{Early pointers}

Critics of the trial said that early tests had predicted Merck's vaccine wouldn't work. They pointed to monkey experiments showing that the vaccine was effective only in animals infected with a weak virus or in those with genetic resistance to the virus. At the annual Conference on Retroviruses and Opportunistic Infections in Boston, Massachusetts in February, Harvard University's Ronald Desrosiers asked an audience of thousands, "Should we be surprised that the Merck product failed to show any efficacy in human trials?" His answer: "Certainly not."

The field needed to understand why the vaccine hadn't worked, and Corey felt the urgency the most. His network had banked on the T-cell approach and planned clinical trials for a roster of new candidates that were similar to Merck's. The most advanced of these was the Partnership for AIDS Vaccine Evaluation (PAVE) trial, which had been scheduled to start in a month's time. PAVE would test whether an injection of HIV genes followed 
by an adenoviral shot could boost T-cell responses in 8,500 volunteers.

After the STEP results were announced, the PAVE trial was put on hold and scaled down. Soon, scientists such as Desrosier were urging the NIAID to kill it outright: "There is no rational basis for believing that any of the [vaccine] products in the pipeline have any reasonable hope of being effective," Desrosiers said at the February conference. He and 12 other scientists wrote to Fauci, urging him to shift $\mathrm{NIH}$ funding towards more basic research. A battle was brewing and millions of dollars were at stake. Should vaccine researchers conduct any more large and expensive clinical trials? Or should they go back to more basic research that might help them design better candidates years down the line?

The arguments came to a head at a March summit organized by the NIAID. Like Desrosiers, many of the 200 or so vaccine researchers at the meeting felt that only basic research could answer the questions that had stymied the search for an HIV vaccine. If they were to pursue the T-cell approach, they needed to know what type of T-cell response could stop the infection from establishing a fatal foothold in the body. If the T-cell approach was doomed, they had to resurrect the antibody approach, and find out if there was any way to coax the body to make neutralizing antibodies against the virus.

\section{Money matters}

Their arguments won the day. Fauci agreed at the meeting that the NIAID would shift more money to basic research, which at the time claimed just under half of the agency's \$476million vaccine budget. After the summit, the NIAID made plans to move $\$ 50$ million from product development to basic research over the next few years, starting with $\$ 17$ million in 2008. In May, it started out by giving $\$ 4$ million in redirected dollars to a \$15.6-million programme to fund research on B cells, which make antibodies. Not that clinical development was written off: dozens of phase I and II clinical trials are planned or under way, some funded by NIAID and other government sources, and some backed by private groups.

Then, on 17 July, Fauci announced that the PAVE trial would be cancelled. The $\$ 140$ million that would have funded it would be scaled back for a much smaller study. The decision would cut the budget of Corey's network but would free up between $\$ 5$ million and $\$ 10$ million for basic research. "The differences between STEP and PAVE were not so great as to warrant doing this trial," Fauci said.

The decision will shift the vaccine network's emphasis towards basic research - a move that Corey agrees is necessary. He hopes that this will lead to more promising clinical trials in the future. But when those studies happen, Corey himself might not be there to conduct them. Being the public face of the vaccine effort, he says, can be "more of a burden than a joy".

Making a vaccine against HIV has been so

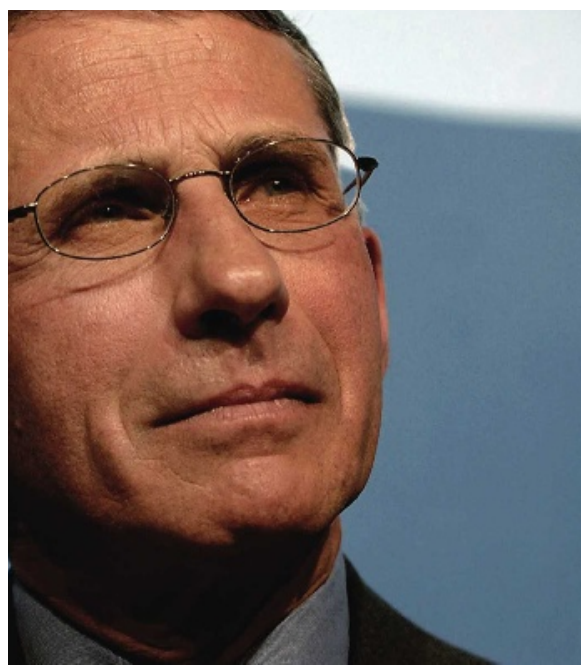

Anthony Fauci's agency devoted more money to basic research after the failed vaccine trial.

much harder than Corey ever imagined, and it may not even happen within his professional career. But Corey knows that he has been fortunate to be a scientific researcher. "You're given money by the US taxpayers to follow your own ideas," Corey says. "That's a privilege." Even if no vaccine is in hand, Corey hopes that the money has delivered some valuable lessons about HIV. But sometimes he wonders whether he should
"Should we be surprised that the Merck product failed to show any efficacy in human trials? Certainly not."

- Ronald Desrosiers return to the basic molecular virology work that was his first love. "I still hope I am worthy of that," he says.

And while senior researchers at the crisis summit were crying out for basic research and more young scientists, Doyle was quietly getting on with her work. She had made her decision about the job offer in Chicago: she would turn it down. She had become so interested in her new project on HIV that she realized she didn't want to quit the field, even if it meant giving up an opportunity: "I decided I really wanted to work on HIV vaccine design, and this is the best place right now for me to do that," she says.

Doyle had heard about the failed STEP trial and its dramatic aftermath. But it hadn't deterred her. "The field has gotten ahead of itself, and jumped into vaccine design without really knowing how HIV is working," she says. "A lot of work needs to go back to figuring out what makes this virus different."

Doyle hopes that her own work will aid that effort. And so does the NIAID: on 20 May, the agency announced that Nemazee and Burton will receive one of the back-to-basics grants on B-cell biology awarded in the wake of the vaccine summit. The $\$ 2$-million grant will support studies on autoimmunity and neutralizing antibodies, including Doyle's project. At the moment, Doyle is still trying to breed mouse pups carrying genes for the neutralizing antibodies.

\section{Progressive steps}

There are already signs that she might be on the right track, however. Doyle has also made mouse B cells that carry the genes for one of the HIV-neutralizing antibodies. To her surprise, she found that the cells react with DNA. That's intriguing, because antibodies that react with an animal's own DNA are, by definition, autoantibodies. Nemazee is sceptical though, because earlier data told a conflicting story, and Doyle's Petri-dish studies might not predict what actually happens in a human being. He says that Doyle's mice will be a more convincing test of the autoantibody hypothesis.

Doyle's studies may or may not hold the key to an HIV vaccine; basic research never guarantees an answer. But Doyle is exactly the kind of person who should be asking the questions. Young, sharp and fascinated by biology, she is motivated by the same thrill of discovery that brought Corey into science. She, too, knows that she is privileged, even if that privilege involves countless afternoons, like the one she spent earlier this month, sitting alone in a darkened basement, using a cell sorter to analyse tubes full of engineered mouse B cells.

Doyle watched screen after screen of data flash before her eyes on a computer. The data wouldn't yield a magic bullet that day, or possibly ever. But she and many others in the field think that it is work like this in labs around the world that holds the only hope for an HIV vaccine. In the long quest for that vaccine, Corey and his generation of researchers have offered a baton to Doyle and hers - and Doyle, for one, has taken it, and is off and running.

Erika Check Hayden is a senior reporter for Nature based in San Francisco.

\footnotetext{
1. Flynn, N. M. et al. J. Infect. Dis. 191, 654-665 (2005).

2. Pitisuttithum, P. et al. J. Infect. Dis. 194, 1661-1671 (2006).

3. Haynes, B. F. et al. Science 308, 1906-1908 (2005).
}

See Editorial, page 551. 